\title{
Cladocera distribution along an environmental gradient on the Cerrado-Amazon ecotone: a preliminary study
}

\author{
Distribuição de Cladocera ao longo de um gradiente ambiental no ecótono \\ Cerrado-Amazônia: um estudo preliminar
}

\section{Leandro Schlemmer Brasil ${ }^{1 *}$ (D), Ana Luiza-Andrade ${ }^{1}$ (D), Tiago Borges Kisaka² (D), Paulo Ilha ${ }^{3}$ (D) and Francisco Diogo Rocha Sousa ${ }^{4}$}

\author{
${ }^{1}$ Programa de Pós-graduação em Zoologia, Universidade Federal do Pará - UFPA, R. Augusto \\ Corrêa, 1, Bairro Guamá, CEP 66075-110, Belém, PA, Brasil \\ ${ }^{2}$ Departamento de Ecologia, Universidade de Brasília - UnB, Campus Universitário Darcy Ribeiro, \\ Bloco E, s/n, $1^{\circ}$ andar, Asa Norte, CEP 70919-900, Brasília, DF, Brasil \\ ${ }^{3}$ Instituto de Pesquisa Ambiental da Amazônia - IPAM, R. Horizontina, 104, Centro, \\ CEP 78640-000, Canarana, MT, Brasil \\ ${ }^{4}$ Unidade Acadêmica Especial de Ciências Biológicas, Universidade Federal de Jataí - UFJ, BR 364, \\ Km 195, 3800, CEP 75801-615, Jataí, GO, Brasil \\ *e-mail: brasil_biologia@hotmail.com
}

Cite as: Brasil, L.S et al. Cladocera distribution along an environmental gradient on the CerradoAmazon ecotone: a preliminary study. Acta Limnologica Brasiliensia, 2019, vol. 31, e29

Abstract: Aim: Our objective in this study is to understand Cladocera species distribution along an environmental gradient in forest and cropland landscapes in the southern Amazon. Methods: We collected Cladocera communities and environmental variables from five streams and verified their associations with a Redundancy Analysis. Results: Acroperus tupinamba, Alonella dadayi e Kisakiellus aweti were mostly associated to sites with higher canopy cover. Anthalona neotropica, Anthalona verrucose and Flavalona iheringula occurred exclusively in site with more thalweg depth. Conclusions: If these results are confirmed Cladocera stream communities are affected by changes in land use. Further studies in this line are extremely necessary to reduce this knowledge gap.

Keywords: change in-stream; land use change; arc of deforestation.

Resumo: Objetivo: Nosso objetivo neste estudo é entender a distribuição de espécies de Cladocera ao longo de um gradiente ambiental em florestas e paisagens agrícolas no sul da Amazônia. Métodos: Coletamos comunidades de Cladocera e variáveis ambientais em cinco riachos e verificamos suas associaçóes com uma Análise de Redundância. Resultados: Acroperus tupinamba, Alonella dadayi e Kisakiellus aweti foram mais associados a locais com maior cobertura do dossel. Já Anthalona neotropica, Anthalona verrucose e Flavalona iheringula ocorreram exclusivamente no local com maior profundidade de talvegue. Conclusóes: Se estes resultados forem confirmados, as comunidades de Cladocera de riachos são afetadas por mudanças no uso da terra. Mais estudos nessa linha são extremamente necessários para reduzir essa lacuna de conhecimento.

Palavras-chave: mudanças no riacho; mudanças no uso da terra; arco do desmatamento. 


\section{Introduction}

Agriculture expansion is responsible for high rates of deforestation at the "Arch of Deforestation" region, an extensive area in the Cerrado-Amazon ecotone which is currently undergoing strong land conversion and frontier settlement (Brando et al., 2013). The conversion of natural landscapes in cropland systems causes steep environmental changes and is the main responsible for the deterioration of the freshwater ecosystems (Leal et al., 2018). Such disturbances might disrupt biotic communities such as fish and aquatic invertebrates (Montag et al., 2019). In this sense, it is of major importance to have knowledge about the identity of the species, what is their distribution and how they interact with the environmental conditions (Hortal et al., 2015).

Microcrustaceans of the Superorder Cladocera are important in the food web of freshwater ecosystems because of their trophic features (Santos et al., 2010) as the majority of species are filters, scrapers or collectors of organic matter. At the same time, they are part of the diet of other invertebrates, fishes and aquatic birds (Elmoor-Loureiro \& Soares, 2010). Shortfalls in Cladocera are mostly related to small lotic systems, a type of ecosystem that does not receive a lot of research focus when compared to lentic ecosystems, due to the unfavourable conditions for the establishment of large populations (Sousa \& Elmoor-Loureiro, 2013). For the southern Amazon region, there is only a precursory species list (Sousa \& Elmoor-Loureiro, 2018), with no information about the relation of those species with the different environmental conditions. A reason for this lotic shortfall for Cladocera is that most studies for the group are restricted to lentic ecosystems (Ghidini \& Santos-Silva, 2011). Nevertheless, there is a high relevance in the increase of this knowledge as the relationship between Cladocera and local conditions has recently been explored for the Neotropical region, with results reinforcing the importance of temperature and precipitation for the productivity of freshwater ecosystems (Rocha et al., 2017).

Given the knowledge shortfall about Cladocera communities and the rapid conversion from natural landscapes to cropland systems in the Cerrado-Amazon ecotone, our objective is to understand the relation between the distribution of Cladocera species along an environmental gradient within landscapes of both cropland and forest systems.

\section{Material and Methods}

The sampling took place in August 2017. We sampled five streams that belong to the high Xingu River Basin, located within the Cerrado-Amazon ecotone in the county of Querência, Mato Grosso (Brazil). This region is characterized by rapid agriculture expansion, being inserted within the "Arch of Deforestation" (Figure 1). Three streams ("APP2", "APP2A" and "APPM") are located in micro-basins with a high degree of conservation, composed mainly of primary forests, and two ("TAN1" and "APP CASCAVEL") in micro-basins dominated by croplands.

This region was deforested in the 1970s and underwent a first cycle of logging, being secondarily converted to cattle pasture and finally being gradually converted to agriculture in the (soybean planting in the main crop and corn and millet in the secondary crop) 1990s (Brando et al., 2013). Changes in fish (Ilha et al., 2018, 2019) and Odonata (Brasil et al., 2014a, b) communities have already been documented in this region and related to environmental changes caused by the conversion of the forest into agrosystems.

In each stream, biological sampling was conducted in a transect of $30 \mathrm{~m}$ using a plankton net $(100 \mu \mathrm{m}$ mesh) dragged throughout leaves, tree branches, fine sediments and macrophytes. The material gathered was set in ethanol (70\%) and identified to species level (Sousa \& Elmoor-Loureiro, 2018). Along the transect we measured ten environmental variables: Canopy cover (\%), Average channel depth $(\mathrm{cm})$, Average thalweg depth $(\mathrm{cm})$, Average channel width (m), Width/Depth, Sinuosity, Fine Benthic Organic Matter (\%), Coarse Benthic Organic Mattter (\%), Roots (\%) and Wood (\%). All environmental variables were measured at least three times per transect, at the beginning, middle and in the end. More details on the collection of environmental variables can be seen at Montag et al. (2019).

As we only had five sites (samples) we reduced the number of predictor variables. When the number of descriptor variables is greater than the number of samples, it is very difficult to capture reliable patterns in multivariate analyzes (Legendre \& Legendre, 2012). Therefore, we used a bioenv variable selection method to select the three most important predictors for Cladocera communities using the Vegan package bioenv function (Oksanen et al., 2010).

To verify the relationship of Cladocera species with the environmental gradient we used the matrix of species with the hellinger transformation 

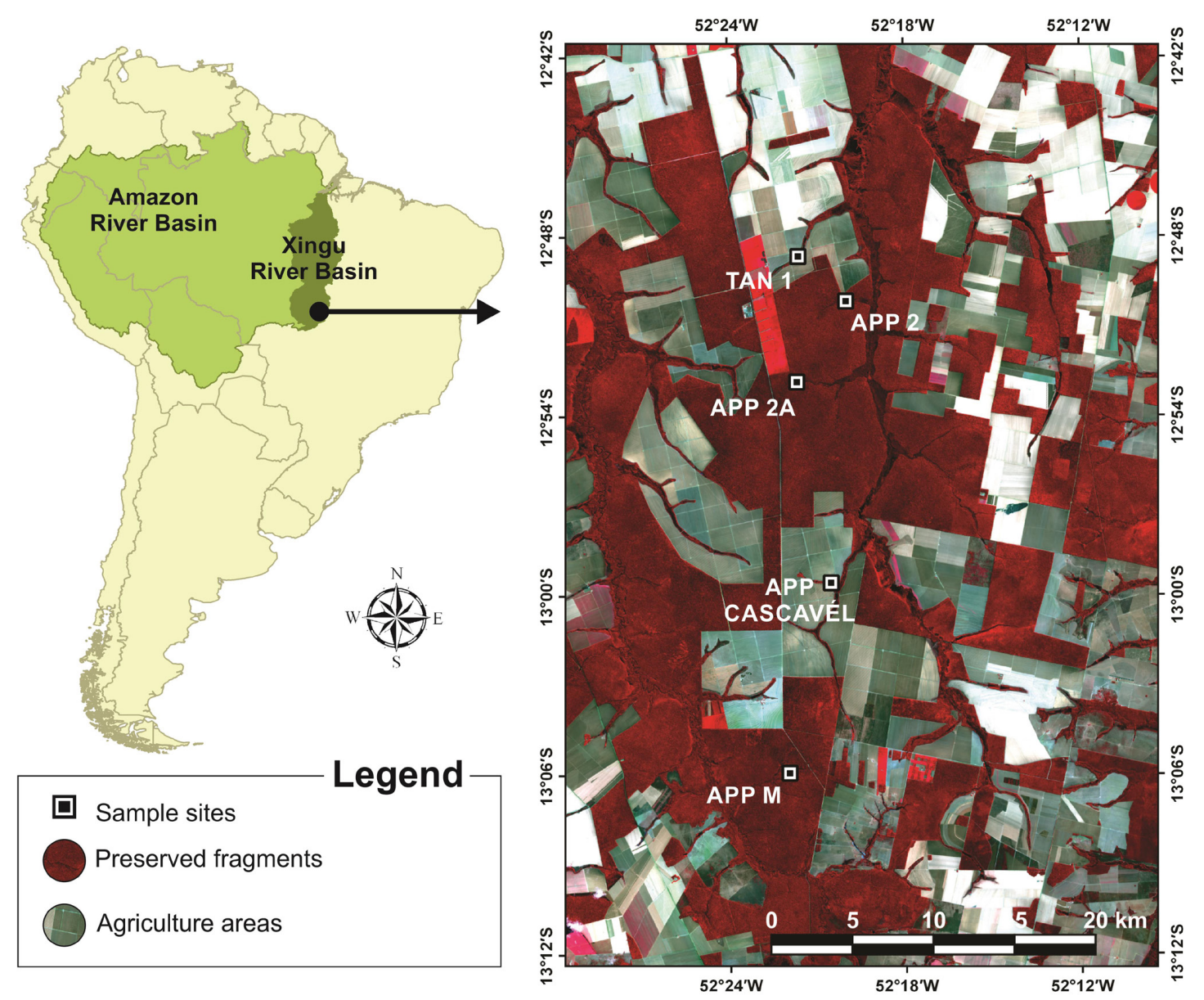

Figure 1. Study area and sampling sites from the Upper Xingu River Basin, satellite image based on Normalized Difference Vegetation Index (NDVI) - composition False Color -bands 5/4/3 - Spacial resolution of 30 meters, LANDSAT 8 (2017).

and the standardized environmental matrix in a Redundancy analysis (RDA) (Legendre \& Legendre, 2012) and tested the significance with ANOVA (Legendre \& Legendre, 2012).

\section{Results and Discussion}

We sampled 22 individuals that were allocated to eight taxa, seven species and one morphospecies (Table 1). The number of individuals by site was of $4.4 \pm 2.07$ (average \pm standard deviation) and of taxa (richness) was of $2.8 \pm 1.30$. The species with the higher abundance were Acroperus tupinamba (Elmoor-Loureiro, 1997) with six individuals that were sampled from three sites, both from cropland and forest micro-basins. This species is known to be found both in large rivers as in their tributaries (Bomfim et al., 2017), there are even records of Acroperus tupinambá in lentic ecosystems (Debastiani-Júnior et al., 2015). We also sampled six individuals of Kisakiellus aweti, gathered from two sites, one cropland and one forest. This species was recently reported in streams and is endemic from the southern Amazon region (Sousa \& Elmoor-Loureiro, 2018).

Based on the ten measured environmental variables (Table 2) the most important for Cladocera communities and used as predictors in the RDA were canopy cover, average channel depth and width/depth. Together they had a 63\% correlation in BIOENV (Table 3). Changes in land use often cause changes in within-stream environmental conditions (Montag et al., 2019). In the Amazon, it has already been demonstrated that deforestation in the riparian zone directly affects canopy cover (Calvão et al., 2016). This increases the amount of light entering the stream channel and consequently changes the water quality, increasing the temperature and decreasing the dissolved oxygen, extremely important conditions for aquatic biota (Martins et al., 2017). 
Table 1. Composition of species with Cladocera abundance values of the five streams located in the transition zone between the Amazon and Cerrado Biomes.

\begin{tabular}{lccccc}
\hline \multicolumn{1}{c}{ Species } & Site $\mathbf{1}$ & Site $\mathbf{2}$ & Site 3 & Site $\mathbf{4}$ & Site 5 \\
\hline Acroperus tupinamba & 3 & 0 & 1 & 2 & 0 \\
Alona ossiani & 0 & 1 & 0 & 0 & 1 \\
Anthalona neotropica & 0 & 0 & 0 & 0 & 1 \\
Anthalona verrucosa & 0 & 0 & 0 & 0 & 1 \\
Flavalona iheringula & 2 & 0 & 0 & 0 & 1 \\
Alonella dadayi & 0 & 0 & 0 & 1 & 0 \\
Kisakiellus aweti & 0 & 0 & 3 & 3 & 0 \\
Macrothrix sp. & 0 & 0 & 0 & 0 & 2 \\
Abundance & $\mathbf{5}$ & $\mathbf{1}$ & $\mathbf{4}$ & $\mathbf{6}$ & $\mathbf{6}$ \\
\hline
\end{tabular}

Table 2. Environmental variables of five streams located in the transition zone between the Amazon and Cerrado Biomes.

\begin{tabular}{cccccccccccc}
\hline Site & Land use & CV & ACD & ATD & ACW & WD & Si & FBOM & CBOM & R & W \\
\hline 1 & forest & 85.294 & 34.563 & 42.7 & 1.983 & 7.042 & 1.107 & 18.918 & 39.189 & 9.459 & 4.054 \\
2 & forest & 94.251 & 22.272 & 25.706 & 1.061 & 7.276 & 1.206 & 20 & 37.333 & 14.666 & 16 \\
3 & forest & 91.577 & 32.945 & 41.066 & 1.448 & 5.022 & 1.037 & 32 & 26.666 & 12 & 16 \\
4 & cropland & 84.759 & 33.763 & 45 & 1.374 & 4.415 & 1.036 & 44 & 8 & 28 & 1.333 \\
5 & cropland & 27.139 & 38.072 & 61.113 & $\mathbf{2 . 0 5 9}$ & 5.802 & 1.183 & 20 & 1.333 & 1.333 & 6.666 \\
Mean \pm SD & & $\mathbf{8 5 \pm 2 8}$ & $\mathbf{3 4 \pm 6}$ & $\mathbf{4 3 \pm 1 3}$ & $\mathbf{1 \pm 0 . 4}$ & $\mathbf{6 \pm 1}$ & $\mathbf{1 \pm 0 . 1}$ & $\mathbf{2 0 \pm 1 1}$ & $\mathbf{2 7 \pm 1 7}$ & $\mathbf{1 2 \pm 1 0}$ & $\mathbf{7 \pm 7}$ \\
\hline
\end{tabular}

$\mathrm{CV} \%=$ Canopy cover (\%); ACD = Average channel depth (cm); ATD= Average thalweg depth (cm); ACW= Average channel width (m); WD= Width/Depth; $\mathrm{Si}=$ Sinuosity; FBOM= Fine Benthic Organic Matter (\%); CBOM= Coarse Benthic Organic Mattter (\%); R= Roots (\%); W= Wood (\%); SD= Standard Deviation.

Table 3. BIOENV result for the correlation between the ten environmental predictors and the communities of Cladocera. In bold the selected model.

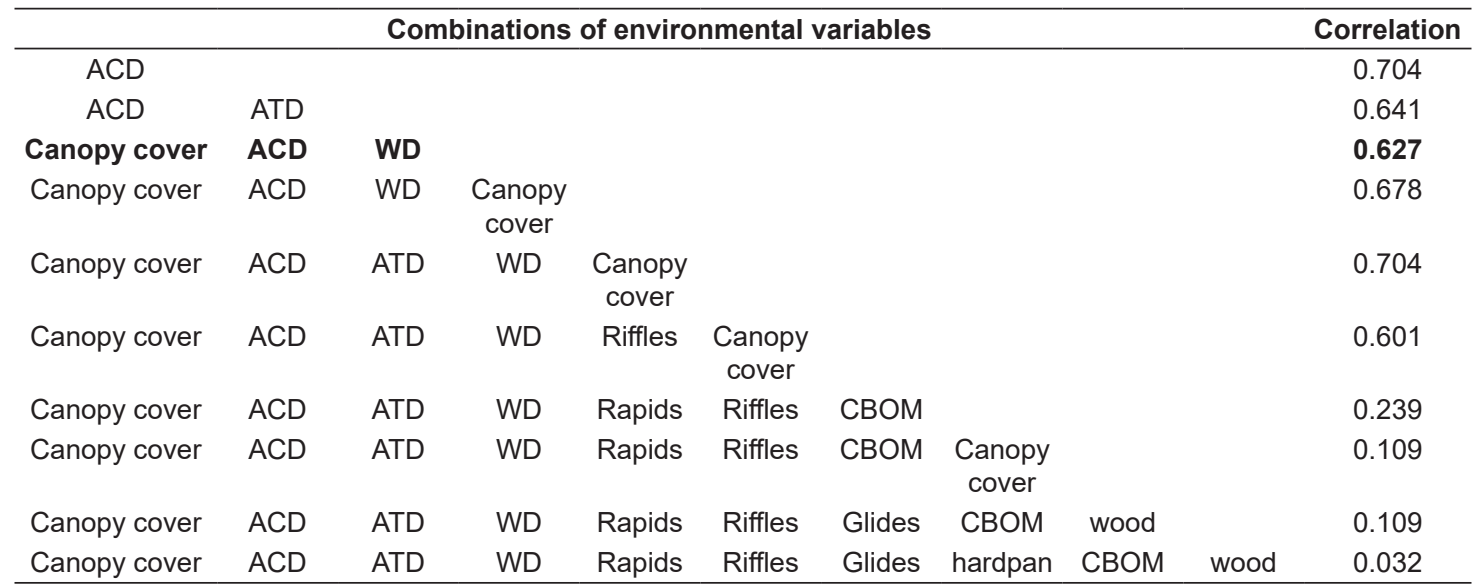

$\mathrm{ACD}=$ Average channel depth; $\mathrm{ATD}=$ Average thalweg depth; WD $=$ Width/Depth; $\mathrm{CBOM}=$ Coarse Benthic Organic Mattter (\%) .

The RDA has shown that species Acroperus tupinamba, Alonella dadayi and Kisakiellus aweti were more associated with sites 3 (APPM) and 4 (APP Cascavel) and had a greater relationship with canopy cover. The species Anthalona neotropica, Anthalona verrucose and Flavalona iheringula occurred exclusively in the site 5 (TAN1) and were associated with talvegue depth (Figure 2, Table 4). The site 5 had the deepest thalvegue. Anthalona verrucose and Flavalona iheringula were also found in a dam (lentic and deep environment) in the same region (Sousa \& Elmoor-Loureiro, 2018). It is therefore possible that these species do not occur, or only occasionally occur in environmentally preserved small streams.

This is an initial effort to explore the relation between Cladocera species distribution and the environmental conditions of streams along an environmental gradient in both forest and cropland areas. If these results are confirmed Cladocera 


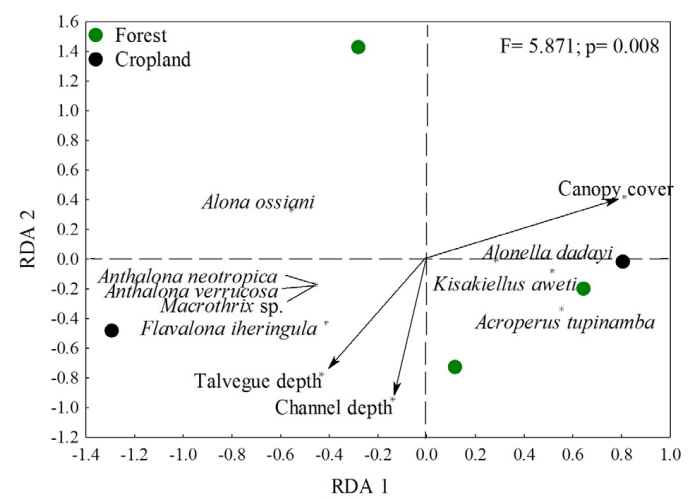

Figure 2. Redundancy analysis of environmental variables and Cladocera communities in Xingu River basin streams in the Cerrado-Amazon ecotone. Green circles are streams surrounded by remnants of native forest and black circles are streams surrounded by cropland.

Table 4. Redundancy Analysis (RDA) details.

\begin{tabular}{lcl}
\hline \multicolumn{3}{c}{ Importance of components } \\
\hline & RDA1 & RDA2 \\
\hline Eigenvalue & 0.419 & 0.196 \\
Proportion Explained & 0.557 & 0.271 \\
Cumulative Proportion & 0.557 & 0.828 \\
\hline \multicolumn{3}{c}{ Loading } \\
\hline \multicolumn{1}{c}{ Variables } & RDA1 & RDA2 \\
\hline Canopy cover & 0.492 & 0.486 \\
Average channel depth & 0.318 & -0.731 \\
Width Depth ratio & -0.66 & -0.201 \\
\hline
\end{tabular}

stream communities may be deeply affected by land use changes. Changes in canopy cover are commonly caused by agriculture and livestock (Leal et al., 2018; Montag et al., 2019) and logging (Calvão et al., 2016) in the Brazilian Amazon. Therefore, the advance of Cladocera research in streams under anthropic pressure may confirm or refute the potential of these organisms as indicators of different environmental conditions. Further studies in this line are extremely necessary to reduce this knowledge gap.

\section{Acknowledgements}

We thank IPAM and Grupo AMaggi for logistical support and CNPq (PELD/TANG 23038.000452/201716). Scholarship: PI (\#88887.136288/2017-00) and LSB (PNPD/UFPA 086/2013) thank CAPES for the grant and ALA (\#141991/2016-0) thanks CNPq for the grant. This work was only possible due to the financial support provided by the Brazilian government for basic research and the quality of Brazil's public universities to produce qualified people.

\section{References}

BOMFIM, F.D.F., MANTOVANO, T., AMARAL, D.C., PALHIARINI, W.S., BONECKER, C.C. and LANSAC-TÔHA, F.A. Adjacent environments contribute to the increase of zooplankton species in a neotropical river. Acta Limnologica Brasiliensia, 2017, 29(0), 1-14. http://dx.doi.org/10.1590/s2179$975 \times 10316$.

BRANDO, P.M., COE, M., DEFRIES, R. and AZEVEDO, A.A. Ecology, economy and management of an agroindustrial frontier landscape in the southeast Amazon. Philosophical Transactions of the Royal Society of London. Series B, Biological Sciences, 2013, 368(1619), 20120152. http://dx.doi. org/10.1098/rstb.2012.0152. PMid:23610163.

BRASIL, L.S., BATISTA, J.D., GIEHL, N.F.D.S., VALADÃO, M.B.X., SANTOS, J.O.D. and DIAS-SILVA, K. Environmental integrity and damselfly species composition in Amazonian streams at the" arc of deforestation" region, Mato Grosso, Brazil. Acta Limnologica Brasiliensia, 2014a, 26(3), 278-287. http://dx.doi.org/10.1590/S2179$975 \times 2014000300007$.

BRASIL, L.S., GIEHL, N.F.D.S., ALMEIDA, S.M., VALADÃO, M.B.X., SANTOS, J.O., PINTO, N.S. and BATISTA, J.D. Does the damming of streams in the southern Amazon basin affect dragonfly and damselfly assemblages (Odonata: Insecta)? A preliminary study. International Journal of Odonatology, 2014b, 7(4), 187-197. http://dx.doi. org/10.1080/13887890.2014.963712.

CALVÃO, L.B., NOGUEIRA, D.S., MONTAG, L.F.A., LOPES, M.A. and JUEN, L. Are Odonata communities impacted by conventional or reduced impact logging? Forest Ecology and Management, 2016, 382, 143-150. http://dx.doi.org/10.1016/j. foreco.2016.10.013.

DEBASTIANI-JÚNIOR, J.R., ELMOORLOUREIRO, L.M.A. and NOGUEIRA, M.G. High taxonomic resolution as a determinant on finding new species and new records in the Río de La Plata basin: a case on Chydoridae (Crustacea: Branchiopoda: Cladocera). Nauplius, 2015, 23(1), 21-30. http:// dx.doi.org/10.1590/S0104-64972015002301.

ELMOOR-LOUREIRO, L.M.A. and SOARES, C.E.A. Cladocerans from gut content of fishes from Guaporé River Basin, MT. Acta Limnologica Brasiliensia, 2010, 22(1), 46-49. http://dx.doi.org/10.4322/ actalb.02201006.

ELMOOR-LOUREIRO, L.M.A. Manualde identificação de cladóceros límnicos do Brasil. Brasília: Editora Universa, Universidade Católica de Brasília, 1997, $156 \mathrm{p}$.

GHIDINI, A.R. and SANTOS-SILVA, E.N.D. Composition, species richness and patterns of nycthemeral vertical distribution of planktonic 
cladocereans in a black water Amazonian lake. Nauplius, 2011, 19(2), 109-122. http://dx.doi. org/10.1590/S0104-64972011000200002.

HORTAL, J., DE BELLO, F., DINIZ-FILHO, J.A.F., LEWINSOHN, T.M., LOBO, J.M. and LADLE, R.J. Seven shortfalls that beset large-scale knowledge of biodiversity. Annual Review of Ecology Evolution and Systematics, 2015, 46(1), 523-549. http://dx.doi. org/10.1146/annurev-ecolsys-112414-054400.

ILHA, P., ROSSO, S. and SCHIESARI, L. Effects of deforestation on headwater stream fish assemblages in the Upper Xingu River Basin, Southeastern Amazonia. Neotropical Ichthyology, 2019, 17(1), 1-12. http://dx.doi.org/10.1590/1982-0224-20180099.

ILHA, P., SCHIESARI, L., YANAGAWA, F.I., JANKOWSKI, K. and NAVAS, C.A. Deforestation and stream warming affect body size of Amazonian fishes. PLoS One, 2018, 13(5), e0196560. http:// dx.doi.org/10.1371/journal.pone.0196560. PMid:29718960.

LEAL, C.G., BARLOW, J., GARDNER, T.A., HUGHES, R.M., LEITÃO, R.P., MAC NALLY, R., KAUFMANN, P.R., FERRAZ, S.F.B., ZUANON, J., DE PAULA, F.R., FERREIRA, J., THOMSON, J.R., LENNOX, G.D., DARY, E.P., RÖPKE, C.P. and POMPEU, P.S. Is environmental legislation conserving tropical stream faunas? A large-scale assessment of local, riparian and catchment-scale influences on Amazonian fish. Journal of Applied Ecology, 2018, 55(3), 1312-1326. http://dx.doi. org/10.1111/1365-2664.13028.

LEGENDRE, P. and LEGENDRE, L.F.J. Numerical ecology. USA: Elsevier, 2012.

MARTINS, R.T., COUCEIRO, S.R., MELO, A.S., MOREIRA, M.P. and HAMADA, N. Effects of urbanization on stream benthic invertebrate communities in Central Amazon. Ecological Indicators, 2017, 73, 480-491. http://dx.doi.org/10.1016/j. ecolind.2016.10.013.

MONTAG, L.F.A., LEÃO, H., BENONE, N.L., MONTEIRO-JÚNIOR, C.S., FARIA, A.P.J., NICACIO, G., FERREIRA, C.P., GARCIA, D.H.A., SANTOS, C.R.M., POMPEU, P.S.,
WINEMILLER, K.O. and JUEN, L. Contrasting associations between habitat conditions and stream aquatic biodiversity in a forest reserve and its surrounding area in the Eastern Amazon. Hydrobiologia, 2019, 826(1), 263-277. http://dx.doi. org/10.1007/s10750-018-3738-1.

OKSANEN, J., BLANCHET, F. G., FRIENDLY, M., KINDT, R., LEGENDRE, P., MCGLINN, D., MICHIN, P.R., O'HARA, R. B., SIMPSON, G. L., SOLYMOS, P.M., HENRY, H., STEVES, E.S., WAGNER, H. Vegan: community ecology package. $R$ package version 1.17-4. Viena: R Development Core Team, 2010 [viewed 23 Sep. 2010]. Available from: http://cran.r-project.org

ROCHA, M.P., HEINO, J., MACHADO-VELHO, L.F., LANSAC-TÔHA, F.M. and LANSAC-TÔHA, F.A. Fine spatial grain, large spatial extent and biogeography of macrophyte-associated cladoceran communities across Neotropical floodplains. Freshwater Biology, 2017, 62(3), 559-569. http:// dx.doi.org/10.1111/fwb.12885.

SANTOS, R.M., NEGREIROS, N.F., SILVA, L.C., ROCHA, O. and SANTOS-WISNIEWSKI, M.J. Biomass and production of Cladocera in Furnas Reservoir, Minas Gerais, Brazil. Brazilian Journal of Biology = Revista Brasileira de Biologia, 2010, 70(3, Suppl), 879-887. http://dx.doi.org/10.1590/S151969842010000400019 . PMid:21085793.

SOUSA, F.D.R. and ELMOOR-LOUREIRO, L.M. Cladocera from the Upper Xingu River Basin with the description of a new genus of the Chydoridae (Crustacea: Branchiopoda: Anomopoda). Zootaxa, 2018, 4418(6), 545-561. http://dx.doi. org/10.11646/zootaxa.4418.6.3. PMid:30313563.

SOUSA, F.D.R. and ELMOOR-LOUREIRO, L.M.A. Cladocerans (Crustacea: Anomopoda and Ctenopoda) of the Sempre Vivas National Park, Espinhaço Range, Minas Gerais, Brazil. Check List, 2013, 9(1), 4-8. http://dx.doi.org/10.15560/9.1.4.

Received: 12 March 2019 Accepted: 18 October 2019 